\title{
Mechanisms of thyroid hormone action
}

\author{
Gregory A. Brent \\ Department of Medicine, VA Greater Los Angeles Healthcare System, and Departments of Medicine and Physiology, \\ David Geffen School of Medicine at UCLA, Los Angeles, California, USA.
}

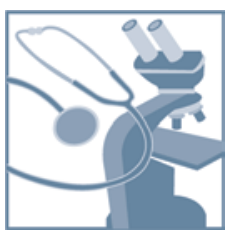

Our understanding of thyroid hormone action has been substantially altered by recent clinical observations of thyroid signaling defects in syndromes of hormone resistance and in a broad range of conditions, including profound mental retardation, obesity, metabolic disorders, and a number of cancers. The mechanism of thyroid hormone action has been informed by these clinical observations as well as by animal models and has influenced the way we view the role of local ligand availability; tissue and cell-specific thyroid hormone transporters, corepressors, and coactivators; thyroid hormone receptor (TR) isoform-specific action; and cross-talk in metabolic regulation and neural development. In some cases, our new understanding has already been translated into therapeutic strategies, especially for treating hyperlipidemia and obesity, and other drugs are in development to treat cardiac disease and cancer and to improve cognitive function.

\section{Introduction}

Thyroid hormone regulates a wide range of genes after its activation from the prohormone, thyroxine (T4), to the active form, triiodothyronine (T3) (1). The signaling pathway is complex and highly regulated due to the expression of cell and tissue-specific thyroid hormone transporters, multiple thyroid hormone receptor (TR) isoforms, and interactions with corepressors and coactivators $(2,3)$. Furthermore, in many cases, thyroid signals are involved in cross-talk with a range of other signaling pathways $(4,5)$. Here, we review how clinical observations and animal models have shaped our understanding of this pathway, and how this insight might be translated to therapeutic approaches for a range of conditions (Table 1).

\section{Overview of thyroid hormone action}

Thyroid hormone is produced by the thyroid gland, which consists of follicles in which thyroid hormone is synthesized through iodination of tyrosine residues in the glycoprotein thyroglobulin $(6,7)$. Thyroid stimulating hormone (TSH), secreted by the anterior pituitary in response to feedback from circulating thyroid hormone, acts directly on the TSH receptor (TSH-R) expressed on the thyroid follicular cell basolateral membrane (8). TSH regulates iodide uptake mediated by the sodium/iodide symporter, followed by a series of steps necessary for normal thyroid hormone synthesis and secretion (9). Thyroid hormone is essential for normal development, growth, neural differentiation, and metabolic regulation in mammals $(2,3,10)$ and is required for amphibian metamorphosis (11). These actions are most apparent in conditions of thyroid hormone deficiency during development, such as maternal iodine deficiency or untreated congenital hypothyroidism, manifesting as profound neurologic deficits and growth retardation (6). More subtle and reversible defects are present when ligand deficiency occurs in the adult (12).

There are two TR genes, TR $\alpha$ and $T R \beta$, with different patterns of expression in development and in adult tissues $(2,13)$. TR $\alpha$ has one T3-binding splice product, TR $\alpha 1$, predominantly expressed in brain, heart, and skeletal muscle, and two non-T3-binding splice products, $T R \alpha 2$ and $T R \alpha 3$, with several additional truncated forms. TR $\beta$ has

Conflict of interest: The author has declared that no conflict of interest exists. Citation for this article: J Clin Invest. 2012;122(9):3035-3043. doi:10.1172/JCI60047. three major T3-binding splice products: TR $\beta 1$ is expressed widely; $T R \beta 2$ is expressed primarily in the brain, retina, and inner ear; and $T R \beta 3$ is expressed in kidney, liver, and lung (2). Human genetics, animal models, and the use of selective pharmacologic agonists have been informative about the role and specificity of the two major isoforms $(2,14,15)$. The selective actions of thyroid hormone receptors are influenced by local ligand availability $(1,16)$; by transport of thyroid hormone into the cell by monocarboxylate transporter 8 (MCT8) or other related transporters (17); by the relative expression and distribution of the TR isoforms (13) and nuclear receptor corepressors and coactivators (18); and, finally, by the sequence and location of the thyroid hormone response element (TRE; refs. 19, 20) (Figure 1). In addition, nongenomic actions of thyroid hormone, those actions not involving direct regulation of transcription by TR, have been increasingly recognized (21). Membrane receptors, consisting of specific integrin $\alpha v / \beta 3$ receptors, have been identified (22) and found to mediate actions at multiple sites, including blood vessels and the heart (23). Several studies have identified direct actions of TR on signal transduction systems $(2,24)$, which may be especially significant in relation to actions in cell proliferation and cancer.

The broad range of genes whose expression is modified by thyroid hormone status makes studying the effect of thyroid hormone action a daunting challenge (25). Many of the actions of thyroid hormone are the result of potentiation or augmentation of other signal transduction pathways (Table 2 and ref. 5). In metabolic regulation, this includes potentiation of adrenergic signaling (26-29) as well as direct interaction with metabolic-sensing nuclear receptors (30-32). Similar direct receptor-to-receptor interactions and competition for overlapping DNA response elements are seen in neural differentiation, as TR interacts with chicken ovalbumin upstream transcription factor 1 (COUP-TF1) and retinoic acid receptor (RAR) $(3,33)$.

TR isoforms differ in length at both amino and carboxy termini and are differentially expressed developmentally and spatially (Figure 1). The structure of $T R \alpha$ and $T R \beta$ are similar in the DNA and ligand domains and differ most in the amino terminus, and it is thought that the increased potency of TR $\alpha$ is related to its amino terminus (34). Fundamental differences in the ligand-binding pocket have permitted the design of ligands that specifically interact with $T R \alpha$ or $T R \beta$ (35), and these have been important tools in the dissection of isoform-specific actions. 


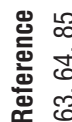

뇽

ปั
กิ่

另
吕

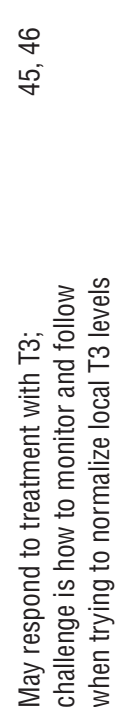

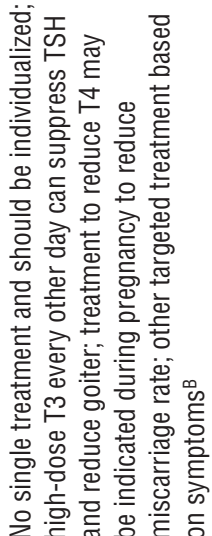

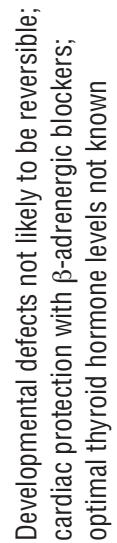

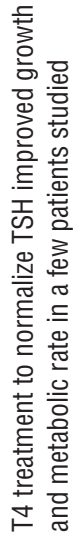

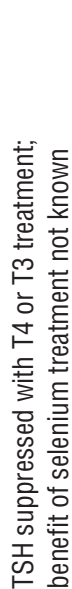

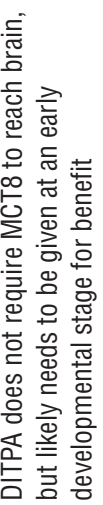

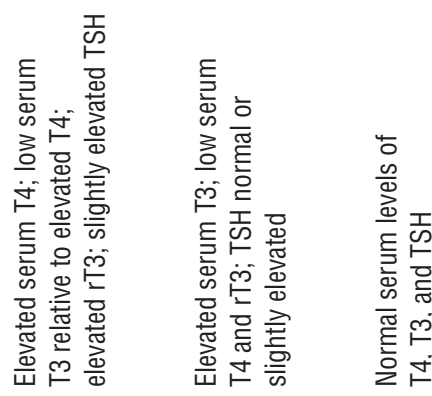

告

产

过官鬲

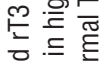

竧豆

형 행

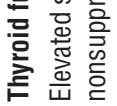

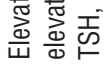

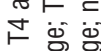

总 든

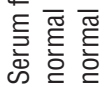

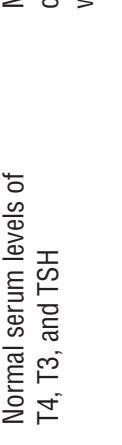


A

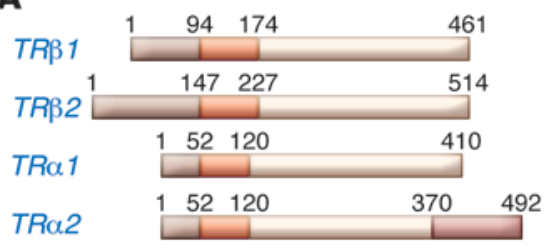

B

T4<smiles>NC(Cc1cc(I)c(Oc2cc(I)c(O)c(I)c2)c(I)c1)C(=O)O</smiles>

T3<smiles>NC(Cc1cc(I)c(Oc2ccc(O)c(I)c2)c(I)c1)C(=O)O</smiles>

rT3<smiles>NC(Cc1ccc(Oc2cc(I)c(O)c(I)c2)c(I)c1)C(=O)O</smiles>

\section{C}
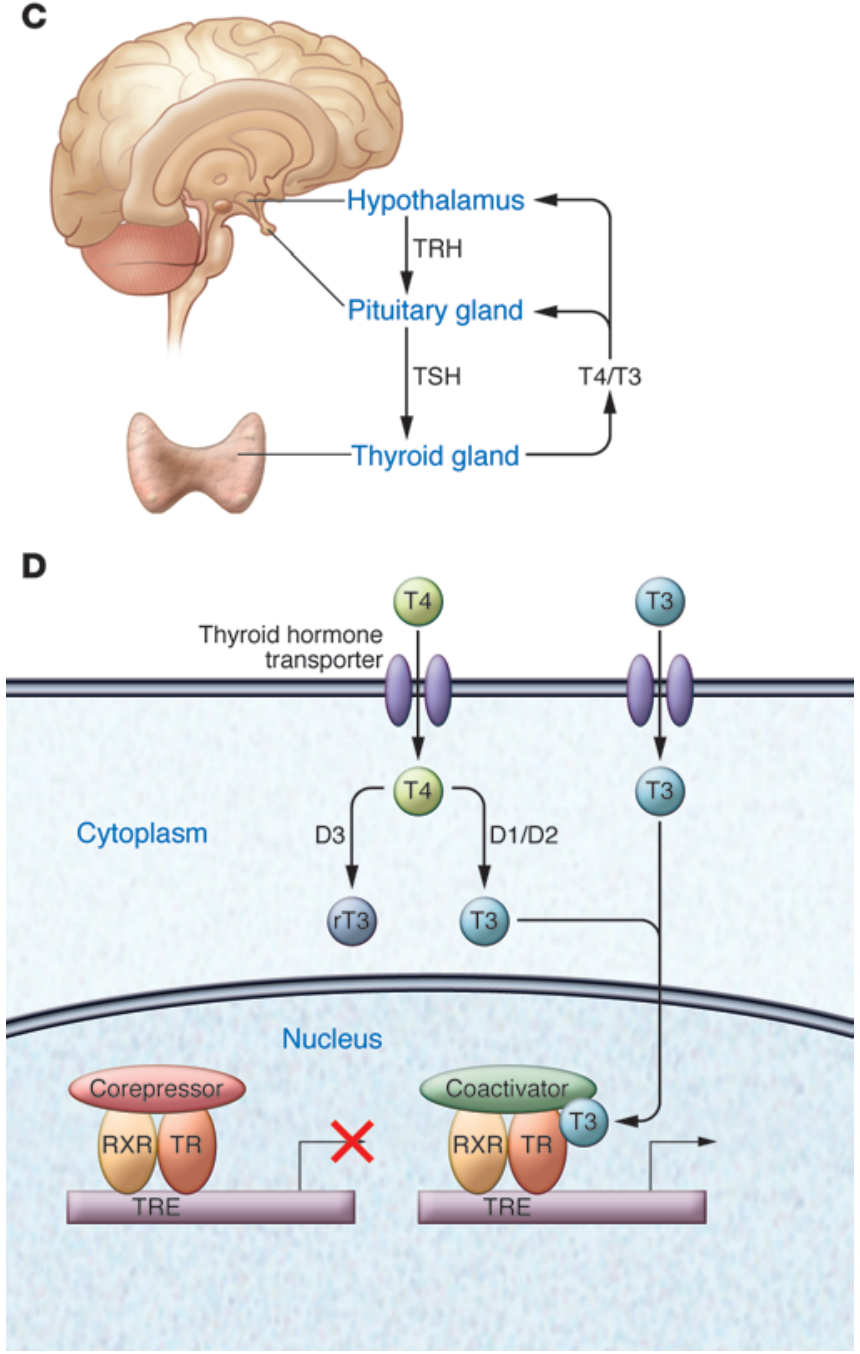

\section{Figure 1}

Nuclear action of thyroid hormone. Shown are the key components required for thyroid hormone action, as demonstrated by a range of clinical observations. (A) The TR gene has 2 major isoforms, TR $\beta$ and $T R \alpha$; the structures of $T R \alpha 1$ and $T R \alpha 2$ (non-T3-binding) and TR $\beta 1$ and TR $\beta 2$ are shown. (B) The major thyroid hormone forms, T4, T3, and rT3. (C) Circulating T4 is converted locally in some tissues by membranebound D2 to the active form, T3. D3 converts T3 to the inactive rT3. (D) In specific tissues, such as brain, transporters such as MCT8 transport T4 and T3 into the cell. Unliganded TR heterodimerizes with RXR and binds to a TRE and then to a corepressor, such as NCoR or SMRT, repressing gene expression. T3 binding to the ligand-binding domain results in movement of the carboxyterminal helix 12, disruption of corepressor binding, and promotion of coactivator binding, which then leads to recruitment of polymerase III and initiation of gene transcription.

TR isoform selectivity for TRE sequences in genes that mediate thyroid hormone response have been seen in some studies, but not all. TRE sequences influence TR isoform interaction with ligand (36) and may influence coactivator recruitment (37). TR interaction with TREs is not static; as has been reported with other nuclear receptors, there is variation in the pattern of binding that may be influenced by the TRE (37). In vitro studies have shown some TR isoform preferences for specific TREs (38), although the ability to translate these findings to in vivo observations are likely limited. Liver gene profiling in TR $\alpha$ and TR $\beta$ gene knockouts demonstrates little in the way of specific genes linked to a TR isoform (25). A recent study, however, suggests that the relative potency of activation may be controlled more by the relative expression of $T R \alpha$ or TR $\beta$ in a tissue, rather than by TR isoform specificity for a specific TRE (39).

\section{Cell membrane thyroid hormone transport and local ligand availability}

Local activation of T3 from the prohormone T4 at the tissue level is increasingly recognized as an important mechanism of regulation of thyroid hormone action (40). The activity of type 2 5 -deiodinase (D2) is regulated by a ubiquitinase/deubiquitinase mechanism. T4 deiodination by D2 results in exposed lysine residues in D2: ubiquitination of these residues reduces D2 activity, and deubiquitination increases D2 activity $(41,42)$. Rodents derive circulating $\mathrm{T} 3$ primarily by the action of type $15^{\prime}$-deiodinase (D1), but humans rely primarily on D2 (1). The inactivation of T4 to form reverse $\mathrm{T} 3$ (rT3), mediated by type 35 -deiodinase (D3), is also important in regulating tissues levels of T3, especially in thyroid axis regulation and sensory development $(43,44)$. Some - but not all - human genetic linkage studies of polymorphisms in D2 have shown an association with obesity and diabetes $(45,46)$.

The relationship between the level of serum T4 and serum $\mathrm{TSH}$, termed the set point, is stable for an individual when repeatedly measured prospectively, but varies significantly between individuals (47). This variability in set point in the population suggests that there is a genetic influence involving one or more genes in the thyroid hormone pathway (48). D2 polymorphisms have been associated with an altered pituitary set point of TSH (49) and with a blunted increase in serum T4 after thyrotropinreleasing hormone-stimulated (TRH-stimulated) acute increase in serum TSH (50). Specific D2 polymorphisms were linked to an improved response in hypothyroid patients to replacement with combined therapy of T4 and T3, rather than T4 alone (51). These 


\section{Table 2}

Thyroid signaling cross-talk with other pathways from in vitro and in vivo models and TR isoform preference

\begin{tabular}{|c|c|c|c|c|}
\hline $\begin{array}{l}\text { Pathway/nuclear factor } \\
\text { or target }\end{array}$ & Process or tissue & TR isoform & Nature of interaction & Reference \\
\hline RAR & Neural development & TR $\alpha 1$ & Inhibits T3 action generally by direct inhibition of TR & $96-98$ \\
\hline Retinoic acid & Brain development & TR $\alpha 1$ & Stimulates MCT8 expression and thyroid transport & 103 \\
\hline COUP-TF1 & $\begin{array}{l}\text { Expressed early in } \\
\text { brain development }\end{array}$ & TR $\alpha 1$ & $\begin{array}{l}\text { Blocks TR binding to a TRE and inhibits T3 induction } \\
\text { of gene expression }\end{array}$ & 99,100 \\
\hline $\operatorname{PPAR} \alpha$ & Liver & TR $\alpha 1$ & Fatty acid oxidation & 26 \\
\hline PPAR $\gamma$ & Liver & $\operatorname{TR} \beta$ & Lipid homeostasis & 110 \\
\hline $\mathrm{LXR} \alpha$ & Liver & $\operatorname{TR} \beta$ & Cholesterol metabolism & 111 \\
\hline LXR & Brain & TR $\alpha 1$ & Cortical layering & 113 \\
\hline p85a subunit of PI3K & Thyroid and liver & $\operatorname{TR} \beta^{A}$ & Cell proliferation; tumorigenesis & 24,130 \\
\hline$\beta$-Catenin & $\begin{array}{l}\text { T3 stimulates expression } \\
\text { in intestinal epithelium }\end{array}$ & TR $\alpha 1$ & Proliferation; tumorigenesis & 133 \\
\hline Adrenergic signaling & White fat & TR $\alpha 1$ & Promotes lipolysis & 30 \\
\hline Adrenergic signaling & Brown fat & $\operatorname{TR} \alpha 1^{\mathrm{B}}$ & Adaptive thermogenesis & $27-29$ \\
\hline Adrenergic signaling & Heart & $\mathrm{TR} \alpha 1$ & Tachycardia & 30 \\
\hline Adrenergic signaling & Bone & $\operatorname{TR} \alpha 1^{\mathrm{C}}$ & Increased bone turnover and bone loss & 89,135 \\
\hline
\end{tabular}

AWild type and mutant. ${ }^{\mathrm{B} T R} \beta$ regulates UCP1. ${ }^{\mathrm{C}}$ Role also for TR $\beta$.

patients may have reduced conversion of T4 to T3 at the tissue level and benefit from replacement with T3. Selenium is required for the enzyme function of all three deiodinases. Individuals with abnormal thyroid hormone metabolism have been described with defects in the SECISBP2 gene, which is required for the synthesis of selenoproteins (52), thus confirming the essential role of this mineral in thyroid metabolism (Table 1).

Thyroid hormone is hydrophobic and was long thought to enter into the cytoplasm by passive diffusion. Thyroid hormone transporters, such as the monocarboxylate (MCT) family and organic anion transporters (OATPs), were identified based on measurable in vitro activity, but the physiologic significance of these transporters was not established early on (17). MCT8 was identified as a specific transporter of thyroid hormone and was reported to be located on the $\mathrm{X}$ chromosome (53). Individuals with a severe form of X-linked mental retardation, Allan-Herndon-Dudley syndrome, manifest with truncal hypotonia, poor head control, and later spasticity and were found to have abnormal thyroid function (elevated serum T4 and rT3 and low T3). When MCT8 was sequenced in these patients, inactivating mutations were identified in some individuals $(54,55)$. More recently, a mouse model with MCT8 inactivation demonstrated that MCT8 is also important for secretion of thyroid hormone (56). Oatp1c1 was shown in a mouse model to be important for thyroid transport across the choroid plexus and into the brain (57).

Thyroid transporters in the developing brain are expressed in specific temporal and spatial patterns $(17,58)$. Individuals with an MCT8 mutation have myelination delays, which are thought to be caused by impaired thyroid hormone action on oligodendrocytes (59). MCT8 is expressed in the hypothalamus, a major site of integration of thyroid hormone feedback and gene regulation (60). Exogenous T3, even in the presence of functional MCT8 transporters, does not act on fetal rat brain, due to the requirement for local production of T3 from T4 (61). Studies of MCT8 have shown that the thyroid hormone metabolite diiodothyropropionic acid (DITPA) does not require MCT8 to enter into cells and is a potential therapy for those affected by MCT8 mutations (62).
It is likely, however, that DITPA therapy will require treatment at an early stage of brain development to be effective. Thus, thyroid hormone action in the brain is modulated by both regional activation and selective uptake into cells, identifying multiple selective targets for therapeutic interventions.

\section{Expanded spectrum of resistance to thyroid hormone: $T R \alpha$ and $T R \beta$ gene mutations}

The major clinical condition associated with impaired nuclear action of thyroid hormone, resistance to thyroid hormone (RTH), was first described in 1967 (63). Clinical features include goiter, elevated circulating thyroid hormone levels, nonsuppressed serum TSH level, clinical euthyroidism, and tachycardia; some individuals also demonstrate attention deficit disorder and deficits of linear growth, hearing, and bone formation (64). The RTH genetic defect was firmly established by a report published more than twenty years ago of a TR $\beta$ mutation in an RTH kindred (65).

The potential phenotype of a TR $\alpha$ mutant RTH syndrome was considered based on the phenotype in animal models with TR $\alpha$ deletion or mutation (66). Recently, two families with different inactivating point mutations in $T R \alpha$ that resulted in receptors with dominant-negative properties have been reported $(67,68)$. The individual with an E403X TR $\alpha$ mutation had chronic constipation, developmental delay, and short stature, with some improvement after levothyroxine therapy (67). The index patient and her father - who was found to have an insertion of thymine at codon 397 of TR $\alpha$, resulting in a frameshift and stop codon at 406 - had short stature, delayed bone development, transient delay in motor development, and mildly impaired cognitive development; they also had some improvement with T4 treatment (68). Levels of free T4 and rT3 in these patients were in the low-normal range, and T3 in the high-normal range, with normal TSH. These reports are a long-awaited complement to the wellcharacterized TR $\beta$ mutations and provide very strong support to the results of genetic and pharmacologic studies indicating that TR isoforms have distinct roles. 
It is of particular interest to compare the phenotype of TR $\alpha$ and TR $\beta$ mutations in humans and determine the in vivo role of TR isoform specificity. An important difference is that TR $\beta$ mediates thyroid hormone feedback to TRH/TSH, and a mutation blunts this feedback, such that more thyroid hormone is produced (8). In a limited study of RTH patients, the reduction in T3 affinity of the TR $\beta$ mutant correlated with the slope of the serum TSH to serum T4 (69). The higher concentration of T4 and T3 in individuals with a $T R \beta$ mutation may compensate for the impaired receptor signaling. In patients with $T R \alpha$ mutations, thyroid hormone feedback is not impaired to the same extent, so thyroid hormone levels are not elevated. This may result in peripheral hypothyroidism, and also points to a potential benefit of levothyroxine therapy in these individuals.

Recently, a report of several patients that are homozygous for $\operatorname{TR} \beta$ mutations demonstrated phenotypic features that represented a combination of those found in individuals heterozygous for a mutation only in TR $\alpha$ or in TR $\beta$ (70). Patients homozygous for TR $\beta$ mutations have a more severe phenotype of RTH - goiter, hearing loss, and much greater elevations of serum T3, T3, and $\mathrm{TSH}-$ than heterozygous individuals. Those homozygous for a TR $\beta$ mutation also have intellectual deficits and growth retardation, more characteristic of deficient action of $T R \alpha(67,68)$. This shows that the mutant $T R \beta$, expressed at sufficiently high levels, antagonizes the actions of $T R \alpha$.

\section{Role of TR interaction with cofactors}

The essential function of gene repression by transcription factor corepressors in development and homeostasis is being increasingly recognized $(71,72)$. Initial in vitro transfection studies with TR expression vectors showed that the unliganded receptor had a repressive effect on genes positively regulated by $\mathrm{T} 3$ and an activating effect on genes normally repressed by $\mathrm{T} 3$ (73). The significance of this property has subsequently been demonstrated by several in vivo models. The mouse model with complete absence of TR $\alpha$ and $T R \beta$ has a milder phenotype than a hypothyroid mouse (74). In the setting of TR $\alpha$ gene deletion, the structural effects of induced neonatal hypothyroidism on the mouse brain were not seen (75). The repressive actions of the unliganded receptor, therefore, have a greater physiologic effect than having no receptor at all (18). The interaction of TR with corepressors has been carefully mapped and tested $(76,77)$. Astapova et al. recently described a mouse model that expressed a version of nuclear receptor corepressor (NCoR) with a mutation in the region that binds TR (78). The disruption of this interaction resulted in a blunted TSH response to thyroid hormone, but enhanced peripheral tissue sensitivity, as the animals were euthyroid despite lower circulating thyroid hormone levels. Interestingly, a mutant NCoR ubiquitously expressed in the background of a TR $\beta$ RTH mutant reversed much of the resistance phenotype seen in that model (79). This indicates that constitutive TR interaction with a corepressor is an important mechanism for RTH.

In a similar approach, mutation of the coactivator interacting domain in TR $\beta$ resulted in resistance to the action of thyroid hormone (80). The interaction of NCoR with histone deacetylase 3 seems to be important for both T3-induced gene activation and repression (81). Another approach to determine the importance of TR coactivator interactions is to determine the impact of coactivator knockouts on thyroid hormone action $(82,83)$. Mice deficient in the coactivator SRC1 showed increased resistance to the action of thyroid hormone (84). These models may provide a mechanis- tic basis for the approximately $15 \%$ of individuals with an RTH phenotype who lack mutations in TR $\beta$, although no cofactor gene mutations have yet been identified in these patients (85).

\section{TR isoforms and neural development}

Highly selective TR isoform requirements have been shown most clearly in models of sensory development, with marked and selective defects of structure and function in the setting of TR isoform inactivation (86). These include development of the inner ear and the cone photoreceptors in the retina $(87,88)$. Another site with specific TR isoform function is bone, both developmentally and in the adult (89). The developmental importance of TR isoforms is coupled with a requirement for specific transporter expression, such as MCT8 expression in the mouse cochlea (58), as well as a requirement for D2 expression to provide local T3, and for D3 to inactivate thyroid hormone and protect from excessive $\mathrm{T} 3$ action during sensitive periods $(86,90)$.

Thyroid hormone interfaces with other signaling pathways in neural development (Table 2). There is a close developmental link between retinoic acid action in early neurologic development and thyroid hormone action (3). In most model systems studied, retinoic acid acts first, followed by thyroid hormone action. Several studies have shown thyroid hormone targets in early neurological development and a requirement for TR $\alpha$ expression $(91,92)$. There are multiple genes whose expression is known to be regulated by both TR and RAR at the TRE (93-95). TR and RAR interact in promoting neural differentiation $(96,97)$, including a repressive action of the unliganded RAR, as has been shown for unliganded TR $(73,98)$.

The orphan nuclear receptor COUP-TF1 is expressed early in neurological development, when thyroid hormone is present, but before the brain is responsive to it (33). Thyroid hormone responsiveness of the brain is associated with reduced expression of COUP-TF1. Numerous thyroid hormone gene targets have been identified with overlapping TR and COUP-TF1 response elements $(99,100)$. The expression of COUP-TF1 blocks TR from binding the TRE, consistent with protection from early T3 stimulation. Calcium calmodulin-dependent kinase IV (CamKIV), a major thyroid hormone target gene in the developing brain, contains a TRE and COUP-TF1 binding site (101). CamKIV is regulated directly by T3 in primary cultured neurons from fetal cortex and promotes the maturation and proliferation of GABAergic interneurons from their precursor cells (102). The timing of the transport of thyroid hormone is tied to RA based on the stimulation of MCT8 gene expression. Using a neuronal cell model, RA was shown to stimulate MCT8 mRNA expression and to confer thyroid hormone transport (103).

TR $\alpha$ protein is expressed in embryonic postmitotic neurons and most adult neurons in the mouse brain, which suggests that thyroid hormone may also have a significant role in the adult brain (104). Thyroid hormone acting through TR $\alpha$ regulates adult hippocampal neurogenesis, which is important in learning, memory, and mood $(105,106)$. Expression of a mutant TR $\alpha$ is associated with more depressive behavior traits in mice (107).

\section{TR isoforms and metabolic regulation}

Specific actions of TR isoforms have been demonstrated for metabolic regulation, including in white fat and brown adipose tissue (BAT). TR $\alpha$ potentiates adrenergic action in white fat, and when $T R \alpha$ is mutated, visceral fat accumulates (30). BAT expresses both $\mathrm{TR} \alpha$ and $\mathrm{TR} \beta$, which have selective roles in adaptive thermogenesis $(28,29)$. Adaptive thermogenesis requires adrenergic stimula- 
tion, T3, D2, uncoupling protein 1 (UCP1), and both TR $\alpha$ and $\operatorname{TR} \beta$ (27). The TR $\alpha$ isoform is required for adrenergic signaling (30), and the TR $\beta$ isoform is required for stimulation of UCP1 (29). In addition to these examples of thyroid hormone potentiation of peripheral adrenergic signaling, thyroid also influences adrenergic signaling centrally (108).

RTH patients with dominant-negative TR $\beta$ mutations have some growth retardation and skeletal defects, but do not consistently present with metabolic abnormalities. However, in a recent study of RTH patients, increased resting energy expenditure was reported (109). These findings suggest that $\mathrm{TR} \alpha$ actions mediating adrenergic sensitivity and fatty acid oxidation may be activated by the higher thyroid hormone levels in RTH patients, as is seen in the heart (5).

TRs engage in cross-talk with a range of nuclear metabolic receptors, including PPAR $\alpha$ (26), PPAR $\gamma$ (110), and liver X receptor (LXR), in metabolic regulation $(111,112)$ and in brain cortical layering (Table 2 and ref. 113). The role of thyroid hormone receptor as an endocrine modulator of metabolic regulation, interacting with other nuclear receptors, PPAR $\gamma$ coactivator 1 (PGC-1), and p160 coactivators and corepressors, has been well described (114).

Our understanding of metabolic cross-talk has been applied directly to therapy with the use of TR $\beta$ agonists for lipid lowering and weight loss $(15,115)$. TR $\beta$ agonists have approximately 10 -fold greater affinity for TR $\beta$ than TR $\alpha$. Initial studies with TR $\beta$ agonists showed a marked preference for action in the liver, efficacy in lowering of cholesterol, and, for some compounds, weight loss, all with little effect on heart or bone. A phase 2 trial of the $\operatorname{TR} \beta$ agonist eprotirome in patients who had not reached LDL target level with a statin demonstrated that the addition of eprotirome produced a dramatic improvement in LDL (116), although cartilage damage in longer-term dog models has led to the withdrawal of these compounds from clinical trials. Although these actions speak strongly for TR isoform specificity, a significant part of the specificity of action of these agents is much greater concentration of the selective agonist compound in the liver compared with the heart (117). A recent study found that the changes in gene expression in the liver were the same after T3 stimulation or exposure to the selective TR $\beta$ agonist GC1 (118). MB07811 achieves liver specificity by being activated after entering hepatocytes by the action of cytochrome P450 to generate the TR $\beta$ agonist MB07344 (119). Interestingly, providing hypothyroid human subjects with only T3 rather than T4, but keeping their TSH in the normal reference range, also results in reduced LDL cholesterol and slight weight loss (120). This modest local hepatic excess of T3 may be sufficient to lower cholesterol and produce weight loss, even when systemic levels are in the normal range.

The thyroid hormone analog DIPTA was found to have some specificity for action on the heart and was studied in a prospective randomized control study in patients with severe heart failure (121). Although improvement in some cardiac parameters was seen, the metabolic effects of weight loss were profound, and the study stopped. The metabolic effects of DITPA - reduction in body weight and LDL cholesterol - provide encouragement for beneficial effects of this class of compound, although stimulation of bone turnover and bone loss by DITPA will limit its therapeutic use (122).

The clinical utility of a TR antagonist has been considered primarily to antagonize the cardiac effects of thyroid hormone, such as ischemia and arrhythmias (123). The structure of the apo TR, without ligand, has not been solved, but important features have been identified from studies of the liganded receptor with agonists and antagonists $(35,123)$. Helix 12 is the carboxyterminal helix of $\mathrm{TR}$, which folds in response to ligand and is essential for TR interaction with coactivators and corepressors (124). TR antagonists have been designed by adding extension groups on TR agonists that interfere with Helix 12 folding (123), although this approach is not specific for $\operatorname{TR} \alpha$ or $\operatorname{TR} \beta$.

\section{Association of thyroid hormone receptor mutations with cancer}

The viral oncogenes v-erbA and v-erbB are the mediators of avian erythroblastosis retrovirus (AEV) induction of erythroleukemias and fibrosarcomas in chickens, first recognized in 1935 (125-127). v-erbA was later recognized as a mutant version of TR $\alpha$, with features that favor oncogenic activity, including deletion of the Helix 12 TR domain, which prevents T3 binding.

The link between the origins of TR and oncogenes is consistent with the role of thyroid hormone signaling and mutant TRs in several forms of cancer. The PV model, in which animals harbor a specific truncation of TR $\beta$, is associated with the development of thyroid cancer (128). In related studies, $T R \beta$ mutations have been identified in a range of cancers, including hepatocellular carcinoma, renal cell carcinoma, erythroleukemias, and thyroid cancer $(127,129)$. TSH-secreting pituitary tumors have also been linked to TR $\beta$ mutations. TR $\beta$ mutants are associated with direct interaction with the regulatory p $85 \alpha$ subunit of PI3K, which leads to activation of PI3K and increased phosphorylation of Akt and mTOR and results in cellular proliferation and migration $(24,130)$. Mutations in TR $\beta$ promote metastatic spread of thyroid cancer (131). TR $\beta$ mutants have also been linked to pituitary tumors by activation of the cyclin D1/cyclin-dependent kinase/retinoblastoma/ E2F pathway (132). TR $\alpha$ directly stimulates transcription of the $\beta$-catenin gene in intestinal epithelial cells and may play a role in tumorigenesis in that tissue (133). Expression of D3, which inactivates thyroid hormone, has been associated with proliferation of malignant keratinocytes in basal cell skin carcinomas (134).

\section{Summary}

The elements required for thyroid hormone action are well recognized, but the interaction among the various pathways has been challenging to understand. Thyroid hormone interacts with a wide variety of signaling pathways, and its action is modulated based on nutritional and iodine status. A range of conditions with disordered thyroid signaling has allowed us to identify key regulatory pathways that are potential therapeutic targets. The availability of TR isoformselective agonists and the recent reports of patients with RTH due to $T R \alpha$ mutations, as well as those homozygous for $T R \beta$ mutations, are strong evidence for TR isoform specificity. The role of the pituitary in responding to a defect in a thyroid hormone action pathway is central to the resulting phenotype. These pathways, as well as the role of thyroid hormone in metabolism, cardiac function, and oncogenesis, are likely to be the focus in applying these findings.

\section{Acknowledgments}

This work was supported by Veterans Affairs Merit Review Funds and NIH grant R01 CA89364.

Address correspondence to: Gregory A. Brent, Department of Medicine, VA Greater Los Angeles Healthcare System, 11301 Wilshire Blvd., Los Angeles, California 90073, USA. Phone: 310.268.3125; Fax: 310.268.4818; E-mail: gbrent@ucla.edu. 
1. Gereben B, et al. Cellular and molecular basis of deiodinase-regulated thyroid hormone signaling. Endocr Rev. 2008;29(7):898-938.

2. Cheng SY, Leonard JL, Davis PJ. Molecular aspects of thyroid hormone actions. Endocr Rev. 2010;31(2):139-170.

3. Williams GR. Neurodevelopmental and neurophysiological actions of thyroid hormone. J Neuroendocrinol. 2008;20(6):784-794.

4. Bernal J. Thyroid hormone receptors in brain development and function. Nat Clin Pract Endocrinol Metab. 2007;3(3):249-259.

5. Liu YY, Brent GA. Thyroid hormone crosstalk with nuclear receptor signaling in metabolic regulation. Trends Endocrinol Metab. 2010;21(3):166-173.

6. Zimmermann MB. Iodine deficiency. Endocr Rev. 2009;30(4):376-408.

7. Rubio IG, Medeiros-Neto G. Mutations of the thyroglobulin gene and its relevance to thyroid disorders. Curr Opin Endocrinol Diabetes Obes. 2009;16(5):373-378.

8. Chiamolera MI, Wondisford FE. Minireview: Thyrotropin-releasing hormone and the thyroid hormone feedback mechanism. Endocrinology. 2009;150(3):1091-1096.

9. Brent GA, Koenig RJ. Thyroid and antithyroid drugs. In: Brunton L, Chabner B, Knollman B, eds. Goodman o Gilman's The Pharmacological Basis of Therapentics. 12th ed. New York, New York, USA: McGraw-Hill Professional; 2010:1129-1161.

10. Tata JR. The road to nuclear receptors of thyroid hormone [published online ahead of print March 17, 2012]. Biochim Biophys Acta. doi:10.1016/ j.bbagen.2012.02.017.

11. Furlow JD, Neff ES. A developmental switch induced by thyroid hormone: Xenopus laevis metamorphosis. Trends Endocrinol Metab. 2006;17(2):40-47.

12. Brent GA, Davies TF. Hypothyroidism and thyroiditis. In: Melmed SP, Larsen PR, Kronenberg HM, eds. Williams Textbook of Endocrinology. 10th ed. Philadelphia, Pennsylvania, USA: Elsevier; 2012:406-439.

13. Oetting A, Yen PM. New insights into thyroid hormone action. Best Pract Res Clin Endocrinol Metab. 2007;21(2):193-208.

14. Brent GA. Tissue-specific actions of thyroid hormone: insights from animal models. Rev Endocr Metab Disord. 2000;1(1-2):27-33.

15. Webb P. Thyroid hormone receptor and lipid regulation. Curr Opin Investig Drugs. 2010;11(10):1135-1142.

16. Bianco AC, Salvatore D, Gereben B, Berry MJ, Larsen PR. Biochemistry, cellular and molecular biology, and physiological roles of the iodothyronine selenodeiodinases. Endocr Rev. 2002; 23(1):38-89.

17. Visser WE, Friesema EC, Visser TJ. Minireview: thyroid hormone transporters: the knowns and the unknowns. Mol Endocrinol. 2011;25(1):1-14.

18. Astapova I, Lee LJ, Morales C, Tauber S, Bilban M, Hollenberg AN. The nuclear corepressor, NCoR, regulates thyroid hormone action in vivo. Proc Natl Acad Sci U S A. 2008;105(49):19544-19549.

19. Shibusawa N, Hollenberg AN, Wondisford FE. Thyroid hormone receptor DNA binding is required for both positive and negative gene regulation. J Biol Chem. 2003;278(2):732-738.

20. Phan TQ, Jow MM, Privalsky ML. DNA recognition by thyroid hormone and retinoic acid receptors: 3,4,5 rule modified. Mol Cell Endocrinol. 2010;319(1-2):88-98.

21. Davis PJ, Zhou M, Davis FB, Lansing L, Mousa SA, Lin HY. Mini-review: Cell surface receptor for thyroid hormone and nongenomic regulation of ion fluxes in excitable cells. Physiol Behav. 2010;99(2):237-239.

22. Bergh JJ, et al. Integrin alphaVbeta 3 contains a cell surface receptor site for thyroid hormone that is linked to activation of mitogen-activated protein kinase and induction of angiogenesis. Endocrinology. 2005;146(7):2864-2871

23. Davis PJ, et al. Overlapping nongenomic and genomic actions of thyroid hormone and steroids. Steroids. 2011;76(9):829-833.

24. Cao X, Kambe F, Moeller LC, Refetoff S, Seo H. Thyroid hormone induces rapid activation of Akt protein kinase B-mammalian target of rapamycinp70S6K cascade through phosphatidylinositol 3-kinase in human fibroblasts. Mol Endocrinol. 2005; 19(1):102-112.

25. Yen PM, et al. Effects of ligand and thyroid hormone receptor isoforms on hepatic gene expression profiles of thyroid hormone receptor knockout mice. EMBO Rep. 2003;4(6):581-587.

26. Liu YY, Heymann RS, Moatamed F, Schultz JJ, Sobel D, Brent GA. A mutant thyroid hormone receptor alpha antagonizes peroxisome proliferator-activated receptor alpha signaling in vivo and impairs fatty acid oxidation. Endocrinology. 2007;148(3):1206-1217.

27. Silva JE. Physiological importance and control of non-shivering facultative thermogenesis. Front Biosci (Schol Ed). 2011;3:352-371.

28. Ribeiro MO, et al. Thyroid hormone-sympathetic interaction and adaptive thermogenesis are thyroid hormone receptor isoform-specific. J Clin Invest. 2001;108(1):97-105.

29. Ribeiro MO, et al. Expression of uncoupling protein 1 in mouse brown adipose tissue is thyroid hormone receptor-beta isoform specific and required for adaptive thermogenesis. Endocrinology. 2010;151(1):432-440.

30. Liu YY, Schultz JJ, Brent GA. A thyroid hormone receptor alpha gene mutation $(\mathrm{P} 398 \mathrm{H})$ is associated with visceral adiposity and impaired catecholamine-stimulated lipolysis in mice. J Biol Chem. 2003;278(40):38913-38920.

31. Yang X, Lamia KA, Evans RM. Nuclear receptors, metabolism, and the circadian clock. Cold Spring Harb Symp Quant Biol. 2007;72:387-394.

32. Sonoda J, Pei L, Evans RM. Nuclear receptors: decoding metabolic disease. FEBS Lett. 2008; 582(1):2-9.

33. Oppenheimer JH, Schwartz HL. Molecular basis of thyroid hormone-dependent brain development. Endocr Rev. 1997;18(4):462-475.

34. Hollenberg AN, Monden T, Wondisford FE. Ligand-independent and-dependent functions of thyroid hormone receptor isoforms depend upon their distinct amino termini. J Biol Chem. 1995;270(24):14274-14280.

35. Figueira AC, et al. Analysis of agonist and antagonist effects on thyroid hormone receptor conformation by hydrogen/deuterium exchange. Mol Endocrinol. 2011;25(1):15-31.

36. Velasco LF, et al. Thyroid hormone response element organization dictates the composition of active receptor. J Biol Chem. 2007;282(17):12458-12466.

37. Liu Y, Xia X, Fondell JD, Yen PM. Thyroid hormone-regulated target genes have distinct patterns of coactivator recruitment and histone acetylation. Mol Endocrinol. 2006;20(3):483-490.

38. Zavacki AM, Harney JW, Brent GA, Larsen PR. Dominant negative inhibition by mutant thyroid hormone receptors is thyroid hormone response element and receptor isoform specific. Mol Endocrinol. 1993;7(10):1319-1330.

39. Chan IH, Privalsky ML. Isoform-specific transcriptional activity of overlapping target genes that respond to thyroid hormone receptors alpha 1 and beta1. Mol Endocrinol. 2009;23(11):1758-1775.

40. Schweizer U, Weitzel JM, Schomburg L. Think globally: act locally. New insights into the local regulation of thyroid hormone availability challenge long accepted dogmas. Mol Cell Endocrinol. 2008;289(1-2):1-9.

41. Sagar GD, et al. The thyroid hormone-inactivating deiodinase functions as a homodimer. Mol Endocrinol. 2008;22(6):1382-1393.

42. Bianco AC. Minireview: cracking the metabolic code for thyroid hormone signaling. Endocrinology. 2011;152(9):3306-3311.

43. Hernandez A, et al. Type 3 deiodinase deficiency results in functional abnormalities at multiple levels of the thyroid axis. Endocrinology. 2007; 148(12):5680-5687.

44. Ng L, et al. Type 3 deiodinase, a thyroid-hormone-inactivating enzyme, controls survival and maturation of cone photoreceptors. J Neurosci. 2010;30(9):3347-3357.

45. Dora JM, Machado WE, Rheinheimer J, Crispim D, Maia AL. Association of the type 2 deiodinase Thr92Ala polymorphism with type 2 diabetes: case-control study and meta-analysis. Eur J Endocrinol. 2010;163(3):427-434.

46. Estivalet AA, et al. D2 Thr92Ala and PPAR $\gamma 2$ Pro12Ala polymorphisms interact in the modulation of insulin resistance in type 2 diabetic patients. Obesity (Silver Spring). 2011;19(4):825-832.

47. Andersen S, Pedersen KM, Bruun NH, Laurberg P. Narrow individual variations in serum $\mathrm{T}(4)$ and $\mathrm{T}(3)$ in normal subjects: a clue to the understanding of subclinical thyroid disease. J Clin Endocrinol Metab. 2002;87(3):1068-1072.

48. Medici M, et al. A large-scale association analysis of 68 thyroid hormone pathway genes with serum TSH and FT4 levels. Eur J Endocrinol. 2011; 164(5):781-788.

49. Hoftijzer HC, et al. The type 2 deiodinase ORFaGly3Asp polymorphism (rs12885300) influences the set point of the hypothalamus-pituitarythyroid axis in patients treated for differentiated thyroid carcinoma. J Clin Endocrinol Metab. 2011; 96(9):E1527-E1533.

50. Peltsverger MY, et al. The -258A/G (SNP rs12885300) polymorphism of the human type 2 deiodinase gene is associated with a shift in the pattern of secretion of thyroid hormones following a TRH-induced acute rise in TSH. EurJ Endocrinol. 2012;166(5):839-845.

51. Panicker $V$, et al. A common variation in deiodinase 1 gene DIO1 is associated with the relative levels of free thyroxine and triiodothyronine. J Clin Endocrinol Metab. 2008;93(8):3075-3081.

52. Dumitrescu AM, et al. Mutations in SECISBP2 result in abnormal thyroid hormone metabolism. Nat Genet. 2005;37(11):1247-1252.

53. Friesema EC, Ganguly S, Abdalla A, Manning Fox JE, Halestrap AP, Visser TJ. Identification of monocarboxylate transporter 8 as a specific thyroid hormone transporter. J Biol Chem. 2003; 278(41):40128-40135.

54. Friesema EC, et al. Association between mutations in a thyroid hormone transporter and severe X-linked psychomotor retardation. Lancet. 2004;364(9443):1435-1437.

55. Dumitrescu AM, Liao XH, Best TB, Brockmann K, Refetoff S. A novel syndrome combining thyroid and neurological abnormalities is associated with mutations in a monocarboxylate transporter gene. Am J Hum Genet. 2004;74(1):168-175.

56. Di Cosmo C, Liao XH, Dumitrescu AM, Philp NJ, Weiss RE, Refetoff S. Mice deficient in MCT8 reveal a mechanism regulating thyroid hormone secretion. J Clin Invest. 2010;120(9):3377-3388.

57. Mayerl S, Visser TJ, Darras VM, Horn S, Heuer H. Impact of Oatp1c1 deficiency on thyroid hormone metabolism and action in the mouse brain. Endocrinology. 2012;153(3):1528-1537.

58. Sharlin DS, Visser TJ, Forrest D. Developmental and cell-specific expression of thyroid hormone transporters in the mouse cochlea. Endocrinology. 2011;152(12):5053-5064.

59 . Bernal J. Thyroid hormone transport in developing brain. Curr Opin Endocrinol Diabetes Obes. 2011;18(5):295-299. 
60. Alkemade A, Friesema EC, Kalsbeek A, Swaab DF, Visser TJ, Fliers E. Expression of thyroid hormone transporters in the human hypothalamus. J Clin Endocrinol Metab. 2011;96(6):E967-E971.

61. Grijota-Martinez C, Diez D, Morreale de Escobar G, Bernal J, Morte B. Lack of action of exogenously administered $\mathrm{T} 3$ on the fetal rat brain despite expression of the monocarboxylate transporter 8 . Endocrinology. 2011;152(4):1713-1721.

62. Di Cosmo C, Liao XH, Dumitrescu AM, Weiss $\mathrm{RE}$, Refetoff S. A thyroid hormone analog with reduced dependence on the monocarboxylate transporter 8 for tissue transport. Endocrinology. 2009;150(9):4450-4458.

63. Refetoff S, DeWind LT, DeGroot LJ. Familial syndrome combining deaf-mutism, stuppled epiphyses, goiter and abnormally high PBI: possible target organ refractoriness to thyroid hormone. JClin Endocrinol Metab. 1967;27(2):279-294.

64. Refetoff S, Dumitrescu AM. Syndromes of reduced sensitivity to thyroid hormone: genetic defects in hormone receptors, cell transporters and deiodination. Best Pract Res Clin Endocrinol Metab. 2007;21(2):277-305.

65. Sakurai A, et al. Generalized resistance to thyroid hormone associated with a mutation in the ligand-binding domain of the human thyroid hormone receptor beta. Proc Natl Acad Sci U S A. 1989; 86(22):8977-8981.

66 . Vennstrom B, Mittag J, Wallis K. Severe psychomotor and metabolic damages caused by a mutant thyroid hormone receptor alpha 1 in mice: can patients with a similar mutation be found and treated? Acta Paediatr. 2008;97(12):1605-1610.

67. Bochukova E, et al. A mutation in the thyroid hormone receptor alpha gene. N Engl J Med. 2012; 366(3):243-249.

68. van Mullem A, et al. Clinical phenotype and mutant TRa1. NEngl J Med. 2012;366(15):1451-1453.

69. Ercan-Fang S, Schwartz HL, Mariash CN, Oppenheimer JH. Quantitative assessment of pituitary resistance to thyroid hormone from plots of the logarithm of thyrotropin versus serum free thyroxine index. J Clin Endocrinol Metab. 2000;85(6):2299-2303.

70. Ferrara AM, Onigata K, Ercan O, Woodhead H, Weiss $\mathrm{RE}$, RefetoffS. Homozygous thyroid hormone receptor $\beta$-gene mutations in resistance to thyroid hormone: three new cases and review of the literature. J Clin Endocrinol Metab. 2012;97(4):1328-1336.

71. Perissi V, Jepsen K, Glass CK, Rosenfeld MG. Deconstructing repression: evolving models of co-repressor action. Nat Rev Genet. 2010;11(2):109-123.

72. Hu X, Lazar MA. Transcriptional repression by nuclear hormone receptors. Trends Endocrinol Metab. 2000;11(1):6-10.

73. Brent GA, Dunn MK, Harney JW, Gulick T, Larsen PR, Moore DD. Thyroid hormone aporeceptor represses T3-inducible promoters and blocks activity of the retinoic acid receptor. New Biol. 1989;1(3):329-336.

74. Gothe S, et al. Mice devoid of all known thyroid hormone receptors are viable but exhibit disorders of the pituitary-thyroid axis, growth, and bone maturation. Genes Dev. 1999;13(10):1329-1341.

75. Morte B, Manzano J, Scanlan T, Vennstrom B, Bernal J. Deletion of the thyroid hormone receptor alpha 1 prevents the structural alterations of the cerebellum induced by hypothyroidism. Proc Natl Acad Sci U S A. 2002;99(6):3985-3989.

76. Zhu XG, Kim DW, Goodson ML, Privalsky ML, Cheng SY. NCoR1 regulates thyroid hormone receptor isoform-dependent adipogenesis. $\mathrm{J} \mathrm{Mol}$ Endocrinol. 2011;46(3):233-244.

77. Hsia EY, Goodson ML, Zou JX, Privalsky ML, Chen HW. Nuclear receptor coregulators as a new paradigm for therapeutic targeting. Adv Drug Deliv Rev. 2010;62(13):1227-1237.

78. Astapova I, et al. The nuclear receptor corepressor
(NCoR) controls thyroid hormone sensitivity and the set point of the hypothalamic-pituitary-thyroid axis. Mol Endocrinol. 2011;25(2):212-224.

79. Fozzatti L, et al. Resistance to thyroid hormone is modulated in vivo by the nuclear receptor corepressor (NCOR1). Proc Natl Acad Sci U S A. 2011;108(42):17462-17467.

80. Alonso M, et al. In vivo interaction of steroid receptor coactivator (SRC)-1 and the activation function-2 domain of the thyroid hormone receptor (TR) beta in TRbeta E457A knock-in and SRC-1 knockout mice. Endocrinology. 2009;150(8):3927-3934.

81. You SH, Liao X, Weiss RE, Lazar MA. The interaction between nuclear receptor corepressor and histone deacetylase 3 regulates both positive and negative thyroid hormone action in vivo. Mol Endocrinol. 2010;24(7):1359-1367.

82 . Sadow PM, et al. Thyroid hormone receptor-specific interactions with steroid receptor coactivator- 1 in the pituitary. Mol Endocrinol. 2003;17(5):882-894.

83. Sadow PM, et al. Specificity of thyroid hormone receptor subtype and steroid receptor coactivator-1 on thyroid hormone action. Am J Physiol Endocrinol Metab. 2003;284(1):E36-E46.

84. Weiss RE, Xu J, Ning G, Pohlenz J, O’Malley BW, Refetoff S. Mice deficient in the steroid receptor co-activator 1 (SRC-1) are resistant to thyroid hormone. EMBO J. 1999;18(7):1900-1904.

85. Weiss RE. "They have ears but do not hear" (Psalms 135:17): non-thyroid hormone receptor beta (nonTRbeta) resistance to thyroid hormone. Thyroid. 2008;18(1):3-5

86. Nunez J, Celi FS, Ng L, Forrest D. Multigenic control of thyroid hormone functions in the nervous system. Mol Cell Endocrinol. 2008;287(1-2):1-12.

87. Roberts MR, Srinivas M, Forrest D, Morreale de Escobar G, Reh TA. Making the gradient: thyroid hormone regulates cone opsin expression in the developing mouse retina. Proc Natl Acad Sci U S A. 2006;103(16):6218-6223.

88. Ng L, Ma M, Curran T, Forrest D. Developmental expression of thyroid hormone receptor beta2 protein in cone photoreceptors in the mouse. Neuroreport. 2009;20(6):627-631.

89. Gogakos AI, Duncan Bassett JH, Williams GR. Thyroid and bone. Arch Biochem Biophys. 2010; 503(1):129-136.

90. Waung JA, Bassett JH, Williams GR. Thyroid hormone metabolism in skeletal development and adult bone maintenance. Trends Endocrinol Metab. 2012;23(4):155-162.

91. Lee LR, Mortensen RM, Larson CA, Brent GA. Thyroid hormone receptor-alpha inhibits retinoic acid-responsive gene expression and modulates retinoic acid-stimulated neural differentiation in mouse embryonic stem cells. Mol Endocrinol. 1994;8(6):746-756.

92. Wang X, Matsuda H, Shi YB. Developmental regulation and function of thyroid hormone receptors and 9-cis retinoic acid receptors during Xenopus tropicalis metamorphosis. Endocrinology. 2008;149(11):5610-5618.

93. Williams GR, Harney JW, Moore DD, Larsen PR, Brent GA. Differential capacity of wild type promoter elements for binding and trans-activation by retinoic acid and thyroid hormone receptors. Mol Endocrinol. 1992;6(10):1527-1537.

94. Gandrillon O, Ferrand N, Michaille JJ, Roze L, Zile $\mathrm{MH}$, Samarut J. c-erbA alpha/T3R and RARs control commitment of hematopoietic self-renewing progenitor cells to apoptosis or differentiation and are antagonized by the v-erbA oncogene. Oncogene. 1994;9(3):749-758.

95. Lee S, Privalsky ML. Heterodimers of retinoic acid receptors and thyroid hormone receptors display unique combinatorial regulatory properties. Mol Endocrinol. 2005;19(4):863-878.

96. Flamant F, Samarut J. Involvement of thyroid hor- mone and its alpha receptor in avian neurulation. Dev Biol. 1998;197(1):1-11.

97. Liu YY, Tachiki KH, Brent GA. A targeted thyroid hormone receptor alpha gene dominant-negative mutation (P398H) selectively impairs gene expression in differentiated embryonic stem cells. Endocrinology. 2002;143(7):2664-2672.

98. Weston AD, Blumberg B, Underhill TM. Active repression by unliganded retinoid receptors in development: less is sometimes more. J Cell Biol. 2003;161(2):223-228.

99. Anderson GW, et al. Chicken ovalbumin upstream promoter-transcription factor (COUP-TF) modulates expression of the Purkinje cell protein-2 gene. A potential role for COUP-TF in repressing premature thyroid hormone action in the developing brain. J Biol Chem. 1998;273(26):16391-16399.

100.Liu YY, Brent GA. A complex deoxyribonucleic acid response element in the rat $\mathrm{Ca}(2+) /$ calmodulin-dependent protein kinase IV gene 5 '-flanking region mediates thyroid hormone induction and chicken ovalbumin upstream promoter transcription factor 1 repression. Mol Endocrinol. 2002;16(11):2439-2451.

101. Morte B, et al. Thyroid hormone regulation of gene expression in the developing rat fetal cerebral cortex: prominent role of the Ca2+/calmodulindependent protein kinase IV pathway. Endocrinology. 2010;151(2):810-820.

102. Manzano J, Cuadrado M, Morte B, Bernal J. Influence of thyroid hormone and thyroid hormone receptors in the generation of cerebellar gammaaminobutyric acid-ergic interneurons from precursor cells. Endocrinology. 2007;148(12):5746-5751.

103. Kogai T, Liu YY, Richter LL, Mody K, Kagechika $\mathrm{H}$, Brent GA. Retinoic acid induces expression of the thyroid hormone transporter, monocarboxylate transporter 8 (Mct8). J Biol Chem. 2010;285(35):27279-27288.

104. Wallis K, Dudazy S, van Hogerlinden M, Nordstrom K, Mittag J, Vennstrom B. The thyroid hormone receptor alpha1 protein is expressed in embryonic postmitotic neurons and persists in most adult neurons. Mol Endocrinol. 2010; 24(10):1904-1916.

105. Desouza LA, Ladiwala U, Daniel SM, Agashe S, Vaidya RA, Vaidya VA. Thyroid hormone regulates hippocampal neurogenesis in the adult rat brain. Mol Cell Neurosci. 2005;29(3):414-426.

106. Kapoor R, et al. Unliganded thyroid hormone receptor alpha1 impairs adult hippocampal neurogenesis. FASEB J. 2010;24(12):4793-4805.

107. Pilhatsch M, Winter C, Nordstrom K, Vennstrom B, Bauer M, Juckel G. Increased depressive behaviour in mice harboring the mutant thyroid hormone receptor alpha 1. Behav Brain Res. 2010;214(2):187-192.

108. Fliers E, Klieverik LP, Kalsbeek A. Novel neural pathways for metabolic effects of thyroid hormone. Trends Endocrinol Metab. 2010;21(4):230-236.

109. Mitchell CS, et al. Resistance to thyroid hormone is associated with raised energy expenditure, muscle mitochondrial uncoupling, and hyperphagia. J Clin Invest. 2010;120(4):1345-1354

110.Araki O, Ying H, Furuya F, Zhu X, Cheng SY. Thyroid hormone receptor beta mutants: Dominant negative regulators of peroxisome proliferatoractivated receptor gamma action. Proc Natl Acad Sci US A. 2005;102(45):16251-16256.

111. Hashimoto K, Matsumoto S, Yamada M, Satoh T, Mori M. Liver X receptor-alpha gene expression is positively regulated by thyroid hormone. Endocrinology. 2007;148(10):4667-4675.

112. Hashimoto K, et al. Cross-talk between thyroid hormone receptor and liver $\mathrm{X}$ receptor regulatory pathways is revealed in a thyroid hormone resistance mouse model. J Biol Chem. 2006;281(1):295-302.

113. Tan XJ, et al. Liver X receptor beta and thyroid hormone receptor alpha in brain cortical layering. Proc 
Natl Acad Sci U S A. 2010;107(27):12305-12310.

114.Feige JN, Auwerx J. Transcriptional coregulators in the control of energy homeostasis. Trends Cell Biol. 2007;17(6):292-301.

115. Ladenson PW. Thyroid hormone analogues: ready for prime time. Thyroid. 2011;21(2):101-102.

116. Ladenson PW, et al. Use of the thyroid hormone analogue eprotirome in statin-treated dyslipidemia. N Engl J Med. 2010;362(10):906-916.

117. Trost SU, et al. The thyroid hormone receptorbeta-selective agonist GC-1 differentially affects plasma lipids and cardiac activity. Endocrinology. 2000;141(9):3057-3064.

118. Yuan $\mathrm{C}$, et al. Identical gene regulation patterns of T3 and selective thyroid hormone receptor modulator GC-1. Endocrinology. 2012;153(1):501-511.

119 . Erion MD, et al. Targeting thyroid hormone receptor-beta agonists to the liver reduces cholesterol and triglycerides and improves the therapeutic index. Proc Natl Acad Sci U S A. 2007;104(39):15490-15495.

120. Celi FS, et al. Metabolic effects of liothyronine therapy in hypothyroidism: a randomized, double-blind, crossover trial of liothyronine versus levothyroxine. J Clin Endocrinol Metab. 2011;96(11):3466-3474.

121. Goldman S, et al. DITPA (3,5-Diiodothyropropionic Acid), a thyroid hormone analog to treat heart failure: phase II trial veterans affairs cooperative study. Circulation. 2009;119(24):3093-3100.

122. Ladenson PW, et al. Effects of the thyromimetic agent diiodothyropropionic acid on body weight, body mass index, and serum lipoproteins: a pilot prospective, randomized, controlled study. J Clin Endocrinol Metab. 2010;95(3):1349-1354.

123. Malm J, Farnegardh M, Grover GJ, Ladenson PW. Thyroid hormone antagonists: potential medical applications and structure activity relationships. Curr Med Chem. 2009;16(25):3258-3266.

124. Souza PC, et al. Helix 12 dynamics and thyroid hormone receptor activity: experimental and molecular dynamics studies of Ile280 mutants. J Mol Biol. 2011;412(5):882-893.

125. Gazzolo L, Samarut J, Bouabdelli M, Blanchet JP. Early precursors in the erythroid lineage are the specific target cells of avian erythroblastosis virus in vitro. Cell. 1980;22(3):683-691.

126. Gandrillon O, Rascle A, Samarut J. The v-erba oncogene-a superb tool for dissecting the involvement of nuclear hormone receptors in differentiation and neoplasia (review). Int J Oncol. 1995;6(1):215-231.

127. Rosen MD, Chan IH, Privalsky ML. Mutant thyroid hormone receptors (TRs) isolated from distinct cancer types display distinct target gene specificities: a unique regulatory repertoire associated with two renal clear cell carcinomas. Mol Endocrinol.2011; 25(8):1311-1325.

128. Furuya F, Ying H, Zhao L, Cheng SY. Novel functions of thyroid hormone receptor mutants: beyond nucleus-initiated transcription. Steroids. 2007;72(2):171-179.

129. Chan IH, Privalsky ML. A conserved lysine in the thyroid hormone receptor-alpha1 DNA-binding domain, mutated in hepatocellular carcinoma, serves as a sensor for transcriptional regulation. Mol Cancer Res. 2010;8(1):15-23.

130.Furuya F, Lu C, Guigon CJ, Cheng SY. Nongenomic activation of phosphatidylinositol 3-kinase signaling by thyroid hormone receptors. Steroids. 2009;74(7):628-634.

131.Lu C, Cheng SY. Extranuclear signaling of mutated thyroid hormone receptors in promoting metastatic spread in thyroid carcinogenesis. Steroids. 2011;76(9):885-891.

132. Furumoto H, et al. An unliganded thyroid hormone beta receptor activates the cyclin D1/cyclindependent kinase/retinoblastoma/E2F pathway and induces pituitary tumorigenesis. Mol Cell Biol. 2005;25(1):124-135.

133.Plateroti M, Kress E, Mori JI, Samarut J. Thyroid hormone receptor alpha1 directly controls transcription of the beta-catenin gene in intestinal epithelial cells. Mol Cell Biol. 2006;26(8):3204-3214.

134.Dentice $M$, et al. Sonic hedgehog-induced type 3 deiodinase blocks thyroid hormone action enhancing proliferation of normal and malignant keratinocytes. Proc Natl Acad Sci U S A. 2007; 104(36):14466-14471.

135. Freitas FR, et al. Spared bone mass in rats treated with thyroid hormone receptor TR beta-selective compound GC-1. Am J Physiol Endocrinol Metab. 2003;285(5):E1135-E1141. 